\title{
Rice Response to Fertilizer Nutrients as Influenced by Integrated Nutrients Management in Vertisols of Chhattisgarh Plain, India
}

\author{
L.K. Srivastava, V.N. Mishra and G.K. Jatav* \\ Soil Science and Agricultural Chemistry, Indira Gandhi Krishi Vishwavidhyalaya, \\ Raipur-492012, Chhattisgarh, India \\ *Corresponding author
}

\section{A B S T R A C T}

\begin{tabular}{|l|}
\hline Ke y w or d s \\
INM, Rice, \\
Stcr, \\
FYM, \\
Vertisol. \\
\hline Article Info \\
\hline Accepted: \\
24 January 2017 \\
Available Online: \\
10 February 2017 \\
\hline
\end{tabular}

Field experiment was conducted to development of fertilizer adjustment equations for rice crop in Vertisol of Chhattisgarh plain region of Chhattisgarh state. Rice crop required $1.52 \mathrm{~kg} \mathrm{~N}, 0.38 \mathrm{~kg} \mathrm{P}$ and $2.03 \mathrm{~kg} \mathrm{~K}$ to produce one quintal grain yield. Fertilizer and soil test efficiencies were estimated 27.75, 24.60 and 87.15 percent and $25.60,66.35$ and 15.85 percent respectively for N P K. The efficiency of FYM in terms of available nutrient was evaluated as 13.85, 7.10 and 11.05 percent respectively. On the basis these parameters, fertilizer $\mathrm{N}, \mathrm{P}_{2} \mathrm{O}_{5}$ and $\mathrm{K}_{2} \mathrm{O}$ were derived for different targeted yield of rice by using FYM as organic component in INM approach.

\section{Introduction}

The demand of food grain by expending population of our country must be met out by increasing production from per unit area as there is very limited scope to increase the cultivated area. It requires extensive research on different aspects to provide a scientific basis for enhancing and sustaining food production as well as soil productivity with minimum environmental degradation. Fertilizers are generally applied to crops on the basis of generalized state level fertilizer recommendations. However, the fertilizer requirement of a crop is not a static one and it may vary for the same crop from soil to soil and even from field to field on the same soil. Soil testing as a diagnostic tool, the value of soil testing in both general and specific terms is to identify soil fertility problems and constraints in an area and to give specific fertilizer recommendation based on soil analysis of a farm holding.

Considering the soil fertility status, crop requirement of nutrients, efficiency of soil and fertilizers and the economic condition of the cultivator, it has now been possible to formulate a yield target oriented fertilizer schedule based on the principle of balanced nutrition of crops. Ramamoorthy et al., (1967) established the theoretical basis and experimental proof for the fact that Liebig's law of minimum operates equally well for $\mathrm{N}$, $\mathrm{P}$ and $\mathrm{K}$. This forms the basis of fertilizer application for targeted yields. 


\section{Materials and Methods}

A field experiment was conducted at the farm of Indira Gandhi Krishi Vishwavidyalaya, Raipur (Chhattisgarh) on soil test crop response correlation with hybrid rice (variety Indira Sona) during two kharif consecutive season in 2008-09 and 2009-10 in Vertisol. The soil of the experimental field comes under the soil order of Vertisol. This soil is locally known as Kanhar and identified as Arang II series. It is clayey in texture with $23.3 \%$ Sand, $21.4 \%$ silt and $55.3 \%$ clay, dark brown to black in color, neutral to alkaline in reaction due to presence of lime concretion in lower horizon. The soil is deep to 1-1.5 meter. The structure varied from coarse angular blocky to massive and cloddy and in few cases from prismatic or columnar. Soil is represented as typical fine montmorillonitic, hyperthermic, udic chromustert. Some physico-chemical properties of experimental soil were analyzed which found $7.8 \mathrm{pH}$ (1:2.5), 0.27 EC $\left(\mathrm{dSm}^{-1}\right), 39.55 \mathrm{CEC}$ (c mol $\left.\left(\mathrm{p}^{+}\right) \mathrm{kg}^{-1}\right), 4.2$ Organic $\mathrm{C}\left(\mathrm{g} \mathrm{kg}^{-1}\right), 224$ Available N $\left(\mathrm{kg} \mathrm{ha}^{-1}\right), 16.28$ Available P $(\mathrm{kg}$ $\left.\mathrm{ha}^{-1}\right)$ and 454 Available $\mathrm{K}\left(\mathrm{kg} \mathrm{ha}^{-1}\right)$. The experiment was conducted according to approved layout plan of All India Coordinated Research project for Investigation on Soil Test Crop Response Correlation (STCR). A special field technique developed by Ramamurthy et al. (1967) was used for this study. The field was divided in to three equal long strips and denoted as $\mathrm{L}_{0}, \mathrm{~L}_{1}$ and $\mathrm{L}_{2}$. Prior to conducting the actual field experiment, a fertility gradient was created by applying the graded doses of $\mathrm{N}, \mathrm{P}$ and $\mathrm{K}$ fertilizer for obtaining the appropriate variation in soil fertility in different strips. Variation in soil fertility with respect to $\mathrm{N}, \mathrm{P}$ and $\mathrm{K}$ were created by applying 100-75-50 and 200-150$100, \mathrm{~kg} \mathrm{ha}^{-1}$ of $\mathrm{N}, \mathrm{P}_{2} \mathrm{O}_{5}$ and $\mathrm{K}_{2} \mathrm{O}$ in $\mathrm{L}_{1}$ and $\mathrm{L}_{2}$ strip, respectively and keeping $\mathrm{L}_{0}$ strip as unfertilized (control). Fodder maize crop was grown during summer season 2008 as a preparatory crop so that fertilizer could interact with soil, plant and microbes and thus become a part of soil system. In this way by growing the exhaust crop, the ranges of soil fertility were created in the fertility strips which were evaluated in terms of variations in fodder yields and soil test values. After the harvest of the fodder crop, the main complex experiment with hybrid rice was conducted in subsequent kharif season. Each strip was divided in to three equal sizes for three levels of FYM $\left(0,5\right.$ and $\left.10 \mathrm{tha}^{-1}\right)$ and was treated as block. A representative sample of applied FYM was analyzed for nutrient content and resulted as 0.4. 0.3, 0.8 per cent $\mathrm{N}, \mathrm{P}$ and $\mathrm{K}$, respectively. The 24 selected fertilizer treatments constituted 4 levels of each of $\mathrm{N}$ $\left(0,60,120\right.$ and $\left.180 \mathrm{~kg} \mathrm{ha}^{-1}\right), \mathrm{P}_{2} \mathrm{O}_{5}(0,40,80$ and $\left.120 \mathrm{~kg} \mathrm{ha}^{-1}\right)$ and $\mathrm{K}_{2} \mathrm{O}(0,40,80$ and 120 $\left.\mathrm{kg} \mathrm{ha}{ }^{-1}\right)$. Theses were distributed in each block of the strips having 8 treatments in each block.

The fertilizer materials were used as urea, single supper phosphate and muriate of potash for the source of $\mathrm{N} P$ and $\mathrm{K}$ nutrient, respectively. Full dose of $\mathrm{P}_{2} \mathrm{O}_{5}$ and $\mathrm{K}_{2} \mathrm{O}$ and $1 / 3^{\text {rd }}$ of $\mathrm{N}$ were applied as basal, remaining $2 / 3^{\text {rd }}$ of $\mathrm{N}$ applied in two equal splits as top dressing at tillering and panicle initiation stages. Grain and straw samples were analyzed for N, P and K content (Piper 1966) and total nutrient uptake was computed using grain and straw yield data. Using the data on grain yield, nutrient uptake, pre-sowing soil available nutrients and fertilizer doses applied the basic parameter, viz. nutrient requirement $\left(\mathrm{kg} \mathrm{q}^{-1}\right)$, contribution of nutrients from soil and fertilizer sources were calculated as described by Ramamoorthy et al. (1967). The contribution of nutrients from applied FYM was estimated by relating the yield with fertilizer nutrients and FYM. These parameters were used for the formulation of fertilizer adjustment equations for deriving fertilizer doses and the soil test based 
fertilizer recommendations were prescribed in the form of ready reckoners for desired yield target of rice under $\mathrm{N}, \mathrm{P}, \mathrm{K}$ alone as well as IPNS.

\section{Results and Discussion}

\section{Soil test levels as affected by past fertilization}

As per the approach suggested by Ramamurthy (1967), variation in soil fertility was deliberately created by adding graded fertilizer doses (Table 1) and maize was sown as exhaust crop during summer season, 2008 so that the added nutrients may naturally transform in to the soil system. Fodder yield of maize in different fertility strips indicated that gradient in fertility level exists. After harvest of maize crop, soil samples were analyzed from each strip. Maize yield and soil test data (Table 1) show that there were little variations in soil test $\mathrm{N}$ (alkaline $\mathrm{KMnO}_{4}-\mathrm{N}$ ). However, the variations in Olsen's $\mathrm{P}$ were quite marked and ammonium acetate extractable- $\mathrm{K}$ did not reflect variations in different fertility strips. Gradient with respect to $\mathrm{P}$ was observed quite marked, as the nature of $\mathrm{P}$ is immobile and subjected to fix in soil particularly high in Vertisols. Phosphorus ions react very quickly with soil constituents to form insoluble compounds depending on the nature of soil, and thus remains in soil. However, there was no gradient created with respect to $\mathrm{N}$ and $\mathrm{K}$ as the nature of $\mathrm{N}$ in soil is very dynamic and its different forms are subjected to losses through leaching volatilization and de-nitrification. The high $\mathrm{K}$ status of the experimental field soil and maintenance of its dynamic equilibrium might be the possible reason for almost the same soil test $\mathrm{K}$ levels in all strips.

\section{Status of available NPK in soil}

Before taking the main complex experiment with rice during kharif season 2008 and 2009, the soil samples from each plot were taken and analyzed for available N, P and K. Table 2 reveals the range and means values of available nutrients ( $\mathrm{N}, \mathrm{P}$ and $\mathrm{K}$ ) during two rice seasons. As discussed in previous section, the data indicate no variations in soil test $\mathrm{N}$ across the fertility strips in both the rice season. Mean values on soil $\mathrm{N}$ ranged from 240-244 and 234-24 kg ha-1 during 2008 and 2009 kharif season, respectively. The level of soil $\mathrm{P}$ increased with respect to fertility strips from $\mathrm{L}_{0}$ to $\mathrm{L}_{2}$. Average soil $\mathrm{P}$ ranged from $13.90-35.30$ and $15.23-36.88 \mathrm{~kg} \mathrm{ha}^{-1}$ in two rice seasons. The available $\mathrm{K}$ status did not reflect with respect to fertility strips indicating that the soil of experimental field is well supplied with K.

\section{Response of rice to added nutrients}

The results (Table 3) showed the range and average values of rice yields in relation to fertility strips during two rice crop seasons. The ranges of rice yields were recorded as $21.54-67.62 \mathrm{q} \mathrm{ha}^{-1}$ with average of $55.23 \mathrm{q}$ $\mathrm{ha}^{-1}$ in $\mathrm{L}_{0}$ strip, 35.86-67.77 $\mathrm{q} \mathrm{ha}^{-1}$ with average of $58.69 \mathrm{q} \mathrm{ha}^{-1}$ in $\mathrm{L}_{1}$ strip and 41.20$67.27 \mathrm{q} \mathrm{ha}^{-1}$ with average of $61.18 \mathrm{q} \mathrm{ha}^{-1}$ in $\mathrm{L}_{2}$ strip during first rice season 2008. It was also noticed that standard deviation (SD) and per cent coefficient of variation $(\mathrm{CV})$ levels were higher in $\mathrm{L}_{0}$ strip and they reduced under $\mathrm{L}_{1}$ and $\mathrm{L}_{2}$ strips. Similar trends were also observed during next rice season 2009. This indicates that variation in soil test values was higher in $\mathrm{L}_{0}$ strip then those of $\mathrm{L}_{1}$ and $\mathrm{L}_{2}$ strips which reflected on crop yields. The increase in rice grain yields with respect to fertility strips may be due to fertility gradient in soil $\mathrm{P}$ status from $\mathrm{L}_{0}$ to $\mathrm{L}_{2}$ strip.

The relation of rice yields with different nutrients as independent variables were derived by regression analysis for both the rice season to evaluate the contribution of soil tests in modifying the crop response to added fertilizer nutrients as presented in the Table 4. 
Results indicate that the larger proportion of variation in the hybrid rice grain yield was accounted for by $\mathrm{N}$ alone. However, its quadratic term gave better fit into the data as evidence from the higher $\mathrm{R}^{2}$ value $(0.80)$ with curvilinear equation (Eq. No. 2) in both the seasons. High response of hybrid rice was attributed to the high $\mathrm{N}$ requirement and being a mobile nature of this element, it is accessible to the plant in the root system sorption zone (Ramamoorthy et al., 1967). Fertilizer $\mathrm{P}_{2} \mathrm{O}_{5}$ and $\mathrm{K}_{2} \mathrm{O}$ were the next to explain the rest of variations.

The $\mathrm{P}$ ions react very quickly with soil constituents to form insoluble compounds and are thus rendered immobile in the soil. Furthermore, the requirement of $\mathrm{P}$ nutrient in rice is lower than $\mathrm{N}$. The curvilinear nature of rice yield response to $\mathrm{P}$ application can therefore be attributed to the above facts. Response of rice to FYM was significant but had less marked as compared to fertilizer N, P and K. Fertilizer N application with FYM could explain 21 and $31 \%$ more grain yield variation (Eq. No. 11) than fertilizer $\mathrm{P}_{2} \mathrm{O}_{5}$ with FYM and fertilizer $\mathrm{K}_{2} \mathrm{O}$ with FYM (Eq. No. $12 \& 13)$. This relation shows the better efficiency of fertilizer $\mathrm{N}$ with FYM application.

The rice responses to FYM and fertilizer N, P, $\mathrm{K}$ in two rice seasons (2008 \& 2009) have also been depicted in Figs. 1 to 4 on above facts. Mahindar Kumar et al., (2009), Pandey et al., (2009), Singh et al., (2009) and Banerjee and Pal (2009) have reported on response of different crops to applied N P K and FYM.

\section{Relationship between yield and nutrient uptake}

A close association was observed between the yield of hybrid rice and total $\mathrm{N}, \mathrm{P}$ and $\mathrm{K}$ uptake in both years 2008-09 and 2009-10.
This relation was used to estimate the nutrient requirement for rice (Table 5). The nutrient requirement (NR) is defined as the amount of nutrient required to produce unit amount of yield per unit quantity of fertilizer applied. The nutrient requirement can be given by the regression coefficient $\left(b_{1}\right)$ of yield $(Y)$ and total nutrient uptake (U).

$\mathrm{Y}=\mathrm{b}_{1} \mathrm{U}$ or $\mathrm{U}=1 / \mathrm{b}_{1} * \mathrm{Y}$

Where, $1 / \mathrm{b}_{1}$ gives the NR

The amount of nutrients absorbed by the crop decides a definite amount of biomass production. The amount of nutrient required to produce one quintal of rice grain during kharif season 2008 was found to be $1.49 \mathrm{~kg}$ $\mathrm{N}, 0.39 \mathrm{~kg} \mathrm{P}$ and $2.13 \mathrm{~kg} \mathrm{~K}$ and $1.54 \mathrm{~kg} \mathrm{~N}$, $0.37 \mathrm{~kg} \mathrm{P}$ and $1.92 \mathrm{~kg} \mathrm{~K}$ in the next kharif season 2009. The overall mean values (Table 6) can be considered as $1.52 \mathrm{~kg} \mathrm{~N}, 0.38 \mathrm{~kg} \mathrm{P}$ and $2.03 \mathrm{~kg} \mathrm{~K}$ to calculate the fertilizer requirement of rice based on the soil test results to achieve a definite yield target.

Several workers have reported the nutrient requirement of different crops at various places. Ramamoorthy et al., (1967) reported for wheat crop which required $2.5 \mathrm{~kg} \mathrm{~N}, 0.8$ $\mathrm{kg} \mathrm{P}_{2} \mathrm{O}_{5}$ and $1.0 \mathrm{~kg} \mathrm{~K}_{2} \mathrm{O}$ for one quintal of grain production. Stanford et al., (1965) reported for sugarcane crop as $0.91 \mathrm{~kg} \mathrm{~N}$ uptake to produce a ton of net cane. Prasad et al. (1981) estimated the nutrient requirement of sugarcane at Sugarcane Research Institute, Pusa, Bihar, for the production of 1 ton of cane as $1.71 \mathrm{~kg} \mathrm{~N}, 0.18 \mathrm{~kg} \mathrm{P}_{2} \mathrm{O}_{5}$ and $1.80 \mathrm{~kg}$ $\mathrm{K}_{2} \mathrm{O}$.

\section{Efficiencies of fertilizer, soil test and FYM}

The efficiencies of fertilizer, soil test and FYM were estimated by using the conventional methods with the help of STCR software developed by IISS, Bhopal. Table 7 
Table.3 Range and mean of grain yields of rice during kharif season 2008 and 2009 in relation to fertility strips

\begin{tabular}{|c|c|c|c|c|c|}
\hline \multirow{2}{*}{$\begin{array}{c}\text { Fertility } \\
\text { Strips }\end{array}$} & \multicolumn{3}{|c|}{ Grain yield $\left(q h^{-1}\right)$} & \multirow{2}{*}{ SD } & \multirow{2}{*}{ CV (\%) } \\
\hline & Minimun & Maximum & Average & & \\
\hline \multicolumn{6}{|c|}{ Kharif season, 2008} \\
\hline $\mathbf{L}_{0}$ & 21.54 & 67.62 & 55.23 & 12.18 & 22.05 \\
\hline $\mathbf{L}_{1}$ & 35.86 & 67.77 & 58.69 & 9.32 & 15.88 \\
\hline $\mathbf{L}_{2}$ & 41.20 & 67.29 & 61.18 & 8.03 & 13.13 \\
\hline All strips & 21.54 & 67.77 & 58.37 & 10.16 & 17.40 \\
\hline \multicolumn{6}{|c|}{ Kharif season, 2009} \\
\hline $\mathbf{L}_{\mathbf{0}}$ & 19.23 & 67.65 & 56.52 & 13.03 & 23.05 \\
\hline $\mathbf{L}_{1}$ & 32.44 & 69.77 & 58.97 & 10.03 & 17.01 \\
\hline $\mathbf{L}_{2}$ & 40.46 & 67.02 & 61.14 & 8.04 & 13.15 \\
\hline All strips & 19.23 & 69.77 & 58.88 & 10.59 & 17.98 \\
\hline
\end{tabular}

Table.4 Selected regression model to account for yield variation of hybrid rice 2008 and 2009

\begin{tabular}{|c|c|c|}
\hline Eq. No. & Model & $\mathbf{R}^{2}$ \\
\hline \multicolumn{3}{|c|}{ Rice, 2008} \\
\hline 1 & $\mathrm{Y}=45.72+0.119 \mathrm{FN}$ & 0.62 \\
\hline 2 & $\mathrm{Y}=39.91+0.335 \mathrm{FN}-0.0011 \mathrm{FN}^{2}$ & 0.80 \\
\hline 3 & $\mathrm{Y}=48.84+0.157 \mathrm{FP}$ & 0.55 \\
\hline 4 & $\mathrm{Y}=45.06+0.347 \mathrm{FP}-0.0015 \mathrm{FP}^{2}$ & 0.63 \\
\hline 5 & $\mathrm{Y}=50.48+0.143 \mathrm{FK}$ & 0.39 \\
\hline 6 & $\mathrm{Y}=47.09+0.325 \mathrm{FK}-0.0015 \mathrm{FK}^{2}$ & 0.46 \\
\hline 7 & $\mathrm{Y}=59.63+0.49 \mathrm{FYM}$ & 0.20 \\
\hline 8 & $\mathrm{Y}=59.19+1.04 \mathrm{FYM}-0.0543 \mathrm{FYM}^{2}$ & 0.18 \\
\hline 9 & $\mathrm{Y}=43.215+0.100 \mathrm{FN}+0.066 \mathrm{FP}$ & 0.64 \\
\hline 10 & $\mathrm{Y}=12.186+0.109 \mathrm{FN}+0.142 \mathrm{SN}$ & 0.63 \\
\hline 11 & $\mathrm{Y}=49.977+0.124 \mathrm{FN}+0.604 \mathrm{FYM}$ & 0.65 \\
\hline 12 & $\mathrm{Y}=44.814+0.158 \mathrm{FP}+0.604 \mathrm{FYM}$ & 0.44 \\
\hline 13 & $\mathrm{Y}=46.678+0.141 \mathrm{FK}+0.604 \mathrm{FYM}$ & 0.34 \\
\hline
\end{tabular}




\section{Rice, 2009}

\begin{tabular}{lll}
\hline 1 & $\mathrm{Y}=46.20+0.120 \mathrm{FN}$ & 0.58 \\
2 & $\mathrm{Y}=39.99+0.351 \mathrm{FN}-0.0012 \mathrm{FN}^{2}$ & 0.79 \\
3 & $\mathrm{Y}=48.84+0.166 \mathrm{FP}$ & 0.58 \\
4 & $\mathrm{Y}=44.33+0.392 \mathrm{FP}-0.0018 \mathrm{FP}^{2}$ & 0.69 \\
5 & $\mathrm{Y}=50.59+0.15 \mathrm{FK}$ & 0.43 \\
6 & $\mathrm{Y}=44.77+0.422 \mathrm{FK}-0.0021 \mathrm{FK}^{2}$ & 0.57 \\
7 & $\mathrm{Y}=60.48+0.445 \mathrm{FYM}$ & 0.16 \\
8 & $\mathrm{Y}=59.99+1.028 \mathrm{FYM}-0.058 \mathrm{FYM}^{2}$ & 0.16 \\
9 & $\mathrm{Y}=43.170+0.099 \mathrm{FN}+0.076 \mathrm{FP}$ & 0.62 \\
10 & $\mathrm{Y}=42.185+0.093 \mathrm{FN}+0.056 \mathrm{FP}+0.047 \mathrm{FK}$ & 0.64 \\
11 & $\mathrm{Y}=42.286+0.127 \mathrm{FN}+0.587 \mathrm{FYM}$ & 0.62 \\
12 & $\mathrm{Y}=44.904+0.167 \mathrm{FP}+0.587 \mathrm{FYM}$ & 0.44 \\
13 & $\mathrm{Y}=46.872+0.147 \mathrm{FK}+0.587 \mathrm{FYM}$ & 0.34 \\
\hline
\end{tabular}

Where, FN, FP and FK are fertilizer $\mathrm{N}, \mathrm{P}_{2} \mathrm{O}_{5}$ and $\mathrm{K}_{2} \mathrm{O}\left(\mathrm{Kg} \mathrm{ha}^{-1}\right)$ respectively. FYM is Farm Yard Manure $\left(\mathrm{t} \mathrm{ha}^{-1}\right)$. $\mathrm{SN}$, SP and SK are soil test values $\left(\mathrm{kg} \mathrm{ha}^{-1}\right)$ for $\mathrm{KMnO}_{4}-\mathrm{N}$, Olsen's $\mathrm{P}$ and ammonium acetate extractable $\mathrm{K}$ and $\mathrm{Y}$ is crop yield.

Table.5 Relation of rice yield (Y) with total nutrient uptake (U)

\begin{tabular}{ccccc}
\hline \multirow{2}{*}{ Nutrient } & \multicolumn{2}{c}{$\mathbf{2 0 0 8}$} & \multicolumn{2}{c}{$\mathbf{2 0 0 9}$} \\
\cline { 2 - 5 } & $\mathbf{Y}=\mathbf{b}_{\mathbf{1}} \mathbf{U}$ & $\mathbf{R}^{\mathbf{2}}$ & $\mathbf{Y}=\mathbf{b}_{\mathbf{1}} \mathbf{U}$ & $\mathbf{R}^{\mathbf{2}}$ \\
\hline $\mathrm{N}$ & $\mathrm{Y}=0.67 \mathrm{U}$ & 0.98 & $\mathrm{Y}=0.65 \mathrm{U}$ & 0.97 \\
$\mathrm{P}$ & $\mathrm{Y}=2.57 \mathrm{U}$ & 0.97 & $\mathrm{Y}=2.67 \mathrm{U}$ & 0.95 \\
$\mathrm{~K}$ & $\mathrm{Y}=0.47 \mathrm{U}$ & 0.96 & $\mathrm{Y}=0.52 \mathrm{U}$ & 0.96 \\
\hline
\end{tabular}

Table.6 Nutrient requirements for hybrid rice

\section{Nutrients Nutrient requirement for one quintal grain yield of hybrid rice $\left(\mathrm{kg} \mathrm{q}^{-1}\right)$}

\begin{tabular}{cccc}
\cline { 2 - 4 } & $\mathbf{2 0 0 8}$ & $\mathbf{2 0 0 9}$ & Mean \\
\hline $\mathrm{N}$ & 1.49 & 1.54 & 1.52 \\
$\mathrm{P}$ & 0.39 & 0.37 & 0.38 \\
$\mathrm{~K}$ & 2.13 & 1.92 & 2.03 \\
\hline
\end{tabular}


Int.J.Curr.Microbiol.App.Sci (2017) 6(2): 1709-1719

Table.7 Efficiencies of fertilizer, soil and FYM for hybrid rice

\begin{tabular}{lccccccccc}
\hline \multirow{2}{*}{ Nutrient } & \multicolumn{3}{c}{ Nitrogen } & \multicolumn{3}{c}{ Phosphorus } & \multicolumn{3}{c}{ Potassium } \\
\cline { 2 - 9 } & $\mathbf{2 0 0 8}$ & $\mathbf{2 0 0 9}$ & Mean & $\mathbf{2 0 0 8}$ & $\mathbf{2 0 0 9}$ & Mean & $\mathbf{2 0 0 8}$ & $\mathbf{2 0 0 9}$ & Mean \\
\hline $\begin{array}{l}\text { Fertilizer } \\
\text { efficiency (\%) }\end{array}$ & 26.1 & 29.4 & 27.75 & 28.3 & 20.9 & 24.60 & 92.9 & 81.4 & 87.15 \\
$\begin{array}{l}\text { Soil Test } \\
\text { efficiency (\%) }\end{array}$ & 25.8 & 25.4 & 25.60 & 61.9 & 70.8 & 66.35 & 16.6 & 15.1 & 15.85 \\
$\begin{array}{l}\text { FYM } \\
\text { efficiency (\%) }\end{array}$ & 13.5 & 14.2 & 13.85 & 7.9 & 6.3 & 7.10 & 12.4 & 9.7 & 11.05 \\
\hline
\end{tabular}

Table.8 Fertilizer adjustment equations for hybrid rice

\begin{tabular}{|c|c|c|c|c|c|c|c|c|c|c|c|}
\hline \multicolumn{3}{|c|}{ S. No. } & \multicolumn{9}{|c|}{ Fertilizer adjustment equations for hybrid rice } \\
\hline \multicolumn{3}{|c|}{1} & \multicolumn{7}{|c|}{$\mathrm{FN}=5.48 \mathrm{Y}-0.92 \mathrm{SN}-0.50 \mathrm{FYM}$} & & \\
\hline \multicolumn{3}{|c|}{2} & \multicolumn{7}{|c|}{$\mathrm{FP}=1.54 \mathrm{Y}-2.70 \mathrm{SP}-0.29 \mathrm{FYM}$} & & \\
\hline \multicolumn{3}{|c|}{3} & \multicolumn{7}{|c|}{$\mathrm{FK}=2.34 \mathrm{Y}-0.18 \mathrm{SK}-0.13 \mathrm{FYM}$} & & \\
\hline \multicolumn{12}{|c|}{$\begin{array}{l}\text { Where, FN, FP and FK are fertilizer N, } \mathrm{P}_{2} \mathrm{O}_{5} \text { and } \mathrm{K}_{2} \mathrm{O}\left(\mathrm{Kg} \mathrm{ha}^{-1}\right) \text { respectively. FYM is Farm Yard Manure }\left(\mathrm{tha}^{-1}\right) \text {. } \\
\mathrm{SN} \text {, SP and SK are soil test values }\left(\mathrm{kg} \mathrm{ha}^{-1}\right) \text { for } \mathrm{KMnO}_{4}-\mathrm{N} \text {; Olsen's } \mathrm{P} \text { and ammonium acetate extractable } \mathrm{K} \text { and } \mathrm{Y} \text { is } \\
\text { crop yield in } \mathrm{q} \mathrm{h}{ }^{-1} \text {. }\end{array}$} \\
\hline \multicolumn{12}{|c|}{$\begin{array}{l}\text { Table.9 Ready reckoners for fertilizer N P and K recommendations based on soil test levels with } \\
5 \text { tons of FYM for hybrid rice (Indira Sona) in Vertisols of Chhattisgarh }\end{array}$} \\
\hline \multirow{2}{*}{\multicolumn{3}{|c|}{$\begin{array}{l}\text { Soil Test levels } \\
\quad\left(\mathrm{kgha}^{-1}\right)\end{array}$}} & \multicolumn{9}{|c|}{ Yield target of hybrid rice $\left(\mathrm{q} \mathrm{ha}^{-1}\right)$} \\
\hline & & & \multicolumn{3}{|c|}{50} & \multicolumn{3}{|c|}{60} & \multicolumn{3}{|c|}{70} \\
\hline SN & $\mathbf{S P}$ & SK & FN & $\mathbf{F P}$ & FK & FN & $\mathbf{F P}$ & FK & FN & FP & FK \\
\hline 150 & 6 & 250 & 134 & 59 & 71 & 188 & 75 & 95 & 243 & 90 & 118 \\
\hline 175 & 8 & 275 & 111 & 54 & 67 & 165 & 69 & 90 & 220 & 85 & 114 \\
\hline 200 & 10 & 300 & 88 & 49 & 62 & 142 & 64 & 86 & 197 & 79 & 109 \\
\hline 225 & 12 & 325 & 65 & 43 & 58 & 119 & 59 & 81 & 174 & 74 & 105 \\
\hline 250 & 14 & 350 & 42 & 38 & 53 & 96 & 53 & 77 & 151 & 69 & 100 \\
\hline 275 & 16 & 375 & 19 & 32 & 49 & 73 & 48 & 72 & 128 & 63 & 96 \\
\hline 300 & 18 & 400 & 00 & 27 & 44 & 50 & 42 & 68 & 105 & 58 & 91 \\
\hline 325 & 20 & 425 & 00 & 22 & 40 & 27 & 37 & 63 & 82 & 52 & 87 \\
\hline 350 & 22 & 450 & 00 & 16 & 35 & 04 & 32 & 59 & 59 & 47 & 82 \\
\hline 375 & 24 & 475 & 00 & 11 & 31 & 00 & 26 & 54 & 36 & 42 & 78 \\
\hline 400 & 26 & 500 & 00 & 05 & 26 & 00 & 21 & 50 & 13 & 36 & 73 \\
\hline
\end{tabular}


Figure.1 Response of hybrid rice to different levels of FYM application and fertilizer of $\mathrm{N}, \mathrm{P}_{2} \mathrm{O}_{5}$, $\mathrm{K}_{2} \mathrm{O}$, in Kharif season 2008 \& 2009
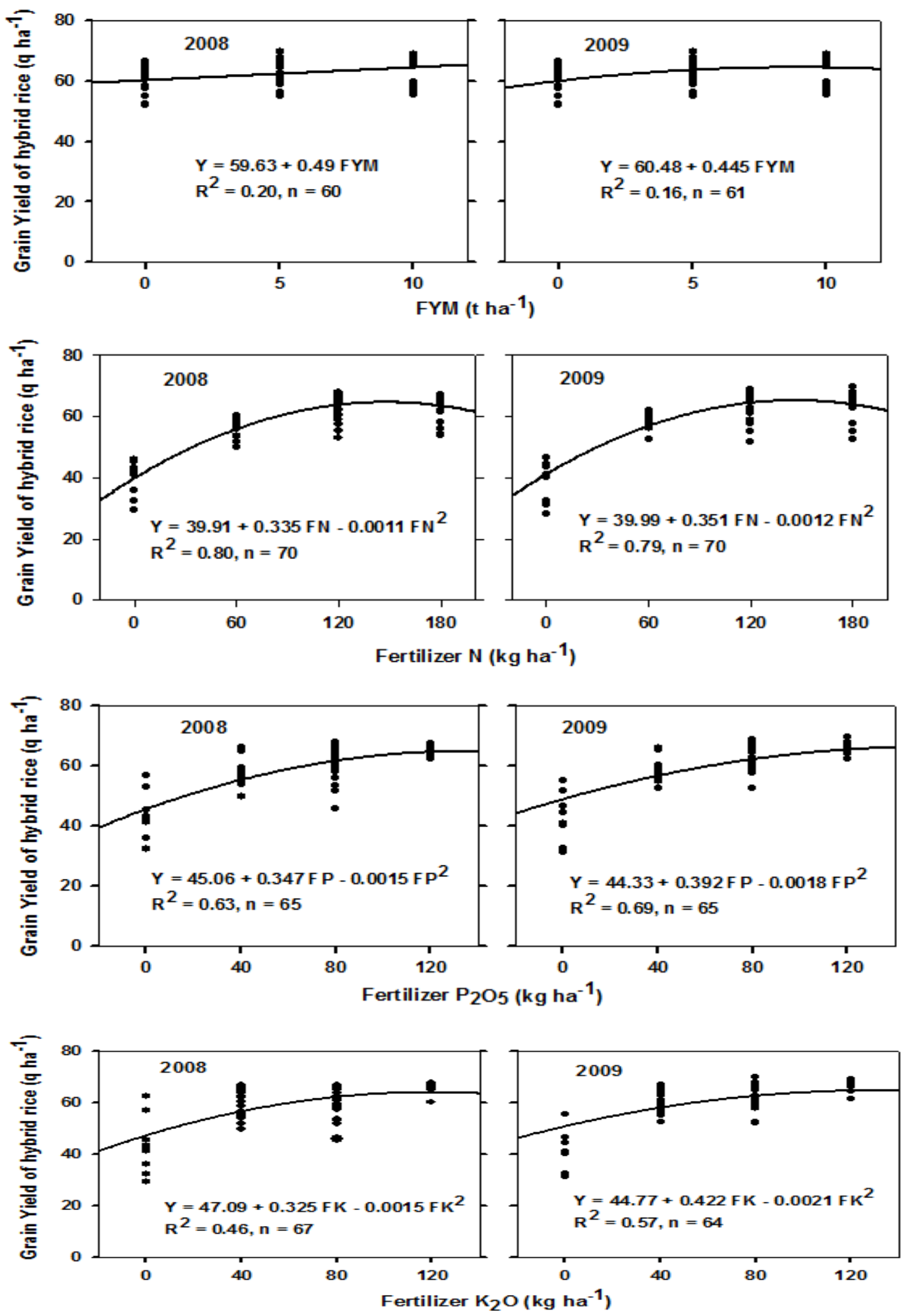
High efficiency of applied fertilizer K observed seems to be due to higher uptake of this nutrient as luxury consumption. In case of cauliflower crop, fertilizer efficiency was observed more than $100 \%$ which shows the experimental field soil is well supplied with native soil $\mathrm{K}$ having high status of ammonium acetate extractable (available) K. Soil test efficiencies for $\mathrm{N}$ and $\mathrm{K}$ were recorded less than fertilizer sources and reverse trend was seen in case of soil test Ramamoorthy et al., (1967) reported the efficiency of soil N, P and $\mathrm{K}$ were 37,14 and 44 per cent, respectively and the efficiency of fertilizer $\mathrm{N}, \mathrm{P}$ and $\mathrm{K}$ were 34,41 and 36 per cent, respectively.

The contributions (\%) from soil and fertilizer nutrients were 21.31 and 44.37 for $\mathrm{N}, 25.38$ and 27.71 for $\mathrm{P}$ and 5.76 and 48.57 for $\mathrm{K}$, respectively for wheat crop. Similarly Santhi et al., (2004) reported the contribution of soil and fertilizer nutrients as 14.13 and 38.28 per cent for $\mathrm{N}, 35.33$ and 56.61 per cent for $\mathrm{P}_{2} \mathrm{O}_{5}$ and 14.33 and 70.03 per cent for $\mathrm{K}_{2} \mathrm{O}$, respectively for onion bulb yield in Inceptisol of Tamil Nadu.

\section{Estimation of fertilizer adjustment equations}

Based on the basic parameters viz. nutrient requirement, efficiencies of fertilizer, soil test and organic source (FYM), fertilizer adjustment equations were evolved for rice crop to achieve a definite yield target. The following equations were evolved for rice for fertilizer $\mathrm{N}, \mathrm{P}_{2} \mathrm{O}_{5}$ and $\mathrm{K}_{2} \mathrm{O}$.

\section{Ready reckoners chart of fertilizer recommendations for hybrid rice}

The ready reckoners for rice with the use of 5 tonnes of FYM are shown in Table 9. The fertilizer requirement reduced with the use of FYM resulting in the saving of chemical fertilizer although it is a meager amount however, application of chemical fertilizer with FYM in integrated manner has beneficial by several ways in terms of soil fertility and physical properties improvement. It is further evident that the fertilizer requirements decreased with increase in soil test values. Therefore, a slightly lower yield target may be considered for a poor resource farmers to obtain maximum profit per unit cost spent on fertilizer, whereas, a higher yield target for a resourceful farmers who are interested for maximum potential production per hectare of land. Hence, for maintaining soil fertility, it is necessary to choose appropriate yield targets and fertilizer use practices that achieve the twin objectives of high yield and maintenance of soil fertility.

Thus the targeted yield approach of fertilizer recommendation ensures nutrient balancing to suit the situations involving different yield goals, soil fertility and resources of the farmer (Dev et al., 1985). Several workers have used this approach of fertilizer prescription (Rashid et al., 1988; Powelson et al., 1989; Yuam and Haung, 1995 and Arya, 2003).

\section{References}

Arya, V.M. 2003. Fertilizer recommendation based on soil test for rice in Inceptisol and Vertisol of Chhattisgarh. M. Sc. (Agriculture) Thesis, Indira Gandhi Krishi Vishwavidyalaya, Krishak Nagar, Raipur, Chhattisgarh.

Banerjee, H. and Pal, S. 2009. Integrated nutrient management for rice-rice cropping system. Oryza, 46(1): 32-36.

Dev, G., Dillion, N.S., Brar, J.S. and Vig, A.C. 1985. Soil test based yield targets for wheat and rice-cropping system. Fertilizer News, 30(5): 42-50.

Mahender Kumar, R., Rama Prasad, A.S., Singh, S.P., Ramesha, M.S. and Subbaiah, S.V. 2009. Responses of hybrids to $\mathrm{N}, \mathrm{P}$ and $\mathrm{K}$ in different rice 
soils. Oryza, 46: (4) 293-298.

Pandey, A.K., Kumar Vipin and Kumar Rajesh 2009. Effect of long-term organic and inorganic nutrients on transplanted rice under rice-wheat cropping system. Oryza, Vol. 46(3): 209-212.

Piper, C.S. 1966. Soil and Plant Analysis, Academic Press, New Delhi., pp.368.

Powelson, A.K. and Willis, W.D. 1989. Crop response to integrated use of inorganic and organic fertilizer on soil microbial biomass dynamic. Agronomy J., 98: 533-539.

Prasad, B., Prasad, C.R., Mishra, G.K., Verma, S.N.P. and Rai, Y. 1981 Fertilizer requirement for different yield targets of sugar cane based on soil test values in calcareous soils of Bihar. Indian Sugar crops J., 8(3): 18-20.

Ramamoorthy, B., Narasimham, R.L., Dinesh, R.S. 1967. Fertilizer application for specific yield target of sonara-64 wheat. Indian Farming, 17: 43-45.

Rashid, A., Bugio, N. and Salim, N. 1988. Calibration of three tests for determining phosphorus fertility of soil to support cereals, legumes and oilseeds. In: Soil test calibration on West Asia and North Africa, Proceeding of the $2^{\text {nd }}$ Regional Workshop 1-6 Sept., pp 86-93.

Santhi, R., Selvakumari, G. and Rani Perumal. 1999. Soil test based fertilizer recommendations under integrated plant nutrition system for rice-rice-pulse cropping sequence. J. Indian Society of Soil Sci., 47: 288-294.

Singh, S.P., Sreedevi, B. and Kumar, R.M. 2009. Integrated nitrogen management for seed production of hybrid rice. Oryza, 46(3): 254-256.

Standford, G., Ayres, A.S. and Doi, M. 1965. Mineralizable soil nitrogen in relation to fertilizer needs of sugarcane in Hawai. Soil Sci., 99: 132-137.

Yuam, L. and Haung, J.G. 1995. Dynamic of soil phosphorus in the rhizos-phere of hybrid rice plants and its utilization. $J$. South West Agricultural Unit, 17(5): $440-442$.

\section{How to cite this article:}

Srivastava, L.K., V.N. Mishra, G.K. Jatav. 2017. Rice Response to Fertilizer Nutrients as Influenced by Integrated Nutrients Management in Vertisols of Chhattisgarh Plain, India. Int.J.Curr.Microbiol.App.Sci. 6(2): 1709-1719. doi: http://dx.doi.org/10.20546/ijcmas.2017.602.191 